\title{
Garaituen bizipenen berreraiketa Armendarizen Silencio roto filmean
}

\author{
La reconstrucción de las experiencias de los vencidos \\ en la película Silencio roto de Armendáriz
}

\author{
Reconstruction of defeated experiences \\ in Armendariz's Silencio roto film
}

\author{
Ander Goikoetxea Pérez ${ }^{\star}$ \\ Universidad del País Vasco/Euskal Herriko Unibertsitatea (UPV/EHU)
}

\begin{abstract}
LABURPENA: Azken hamarkadetan, zinema iraganeko dokumentu bihurtu da testu idatzian eta dokumentu ofizialetan jasotako informazioa osatzeko iturri gisa. Baina XX. mendean eztabaida luzeak izan dira gai honen inguruan, zineak eta historiografiak mesfidantzaz begiratzen bait zioten elkarri. Gaur egun, ordea, autore gehienak ados daude zinema iraganeko dokumentua dela esatean. Zentzu horretan, iraganean girotutako film bati ezin zaio exijitu erabat zehatza eta egiazkoa izatea, baizik eta beti zintzoa izatea. Silencio rotoren bidez, Armendarizek makiaren borroka antifaxista gogoratzen du. Lan honetan aipatutako filmaren eraikuntza narratiboaren hiru elementu nagusiak (pertsonaia, akzioa eta gatazka) identifikatuz eta aztertuz makiaren irudikapena aztertu nahi da. Beste autore batzuek Silencio roto filma aztertu dutela jakinda, lan honek ikuspegi berri batetik heldu nahi dio gaiari, aurreko ikerketen osagarri gisa: zuzendariak 40ko hamarkadako gerrillaren testuinguruan islatu dituen emakume garaituen bizipen basatiak.
\end{abstract}

GAKO-HITZAK: fikzioa; frankismoa; oroimen historikoa; ikus-entzunezko narratiba; indarkeria.

\begin{abstract}
In recent decades, cinema has become a document of the past as a source to complete the information contained in the written text and official documents. But since the twentieth century there have been long discussions on this subject, since the cinema and historiography were looked distrustfully. At present, however, most of the authors agree that cinema is a document of the past. In this sense, a film set in the past cannot be asked to be absolutely accurate and truthful, but is always sincere. With Silencio roto, Armendariz recalls the antifascist struggle of the machine. This paper aims to analyze the representation of the machine by identifying and analyzing the three main elements of the narrative construction of the reference film: characters, action and conflict. Knowing that other authors have studied this film, this paper aims to address the subject from a new perspective, as a complement to previous research. Thus, the director has retaken the question of the guerrilla of the 40's, taking into account the brutal experiences of the defeated.
\end{abstract}

KEYWORDS: fiction; Francoism; historical memory; audiovisual narrative; violence.

\footnotetext{
* Harremanetan jartzeko / Corresponding author: Ander Goikoetxea Pérez. Facultad de Ciencias Sociales y de la Comunicación. Campus de Bizkaia de la UPV/EHU. Barrio Sarriena, s/n (48940 Leioa-Bizkaia) - ander.goikoetxea@ehu.eus - https://orcid.org/0000-0002-3891-2975

Nola aipatu / How to cite: Goikoetxea Pérez, Ander (2021). "Garaituen bizipenen berreraiketa Armendarizen Silencio roto filmean», Zer, 26(50), 105-124. (https://doi.org/10.1387/zer.21867)
}

Jasoa: 2020, ekainak 29; Onartua: 2020, urriak 29.

ISSN 1137-1102 - eISSN 1989-631X / (c) 2021 UPV/EHU

(i) $\odot$ - Lan hau Creative Commons Aitortu-EzKomertziala-LanEratorririkGabe 4.0 Nazioartekoa

cc) ${ }_{\mathrm{BY}}{ }_{\mathrm{NC}}{ }_{\mathrm{ND}}$ lizentzia baten mende dago 


\section{Sarrera}

Kontakizuna errealitatearen irudikapena dela esaten den heinean, eguneroko gertakarien berri zehatza ematen duelako, kontakizuna, azken finean, irreala da, izatez hermetikoa ere delako. Kontakizunaren egitura bera errealitatea baino askoz zurrunagoa eta sistematikoagoa da (Rosenstone, 1997). Hori da, hain zuzen ere, film historikoaren erronka nagusia: filmak alde batera uzten du gertaeren kausen konplexutasuna, eta, gainera, ez du idatzitako historiaren zorroztasunik, beste aukera batzuei ateak itxiz.

Filma ez bezala, errealitatea irekia da. Beraz, kontakizuna itxia da: abiapuntua, garapena eta amaiera ditu, eta, gainera, ordena eta denbora zehatzak. Horregatik kontrajartzen da mundu errealarekin, non elementu estruktural hauek garrantzi txikiagoa duten (Gaudrealult eta Jost, 1995). Hala ere, zenbaiten ustez, irudien bidezko istorioa testu idatzia baino askoz konplexuagoa da, testu batek baino elementu gehiago barneratzen baititu: zinemak gertatutakoa bere osotasunean islatu behar du, guztia kontuan hartuta. Film batek garaiko zapatak, altzariak, jakak, etab. erakutsi behar ditu; horregatik, zinemak interpretatu eta asmatu egin behar du (Martínez Gil, 2013).

Milurteko berria «oroimen historikoa» kontzeptua berreskuratzeko asmoz iritsi da Espainiako Estatuan. Egia da, halaber, kontzeptu hori Gerra Zibilera eta frankismora mugatzen dela kasu gehienetan. Gauzak horrela, xxI. mendeak, joera hori esparru askotan (hainbat kultura-ekoizpenetan, politikan, zientzian, zuzenbidean, eremu akademikoan...) ikus daitekeen aro berria hasi du gerra galdu eta errepresioa jasan zutenak aitortzeko.

Hortaz, gizarteak galtzaileak aitortu nahi izan ditu. Horren erakusgarri da hamaika gizarte-elkarte sortu direla, Euskal Herrian zein Estatuan, gaia sakon lantzen dutenak. Hainbesteko garrantzia hartuz, gaiak politikara jauzi egin zuen mende hasieran. 2007ko abenduan Diputatuen Kongresuak Memoria Historikoari buruzko 52/2007 Legea onartu zuen, galtzaileen aitortza eta ordainerako politikaren lehen planora igaroz. Egia, justizia eta ordaina izan litezke hainbat gizarte-eremutatik egindako banakako ekintza horien guztien aldarrikapen komuna.

Ikertzaile askorentzat, aro berri honen gakoa belaunaldi-aldaketa izan da, gerra bizi izan dutenen bilobek eutsita (Juliá, 2003; Aguilar Fernández, 2006; Saz, 2007; Pagès i Blanch, 2015). Belaunaldi honek ez du harreman zuzenik gerrarekin, bere aitona-amonek bezala, eta ez du bere gurasoek trantsizioaren garapenean duten adinako erantzukizunik. Beraz, hirugarren belaunaldi honek egia jakiteko eskubidea erreibindikatu (nork, zer eta nori), eta hainbat bidetatik hausnartzeko deia egin du, tartean zinemagintza. 
Horri, ordea, zalantza sortzen zaio, ez baita gauza bera historia eta oroimen historikoa, ezta memoria eta haren irudikapena ere. Horregatik, xx. mendetik eztabaida luzeak izan dira horren inguruan, zinea eta historiografia elkarri mesfidati begiratzen zioten bi eremu baitziren. Baina, azken hamarkadetan zinema iraganeko dokumentu bilakatu da, idatzizko testuak eta dokumentu ofizialek jasotakoa osatzen duen informazio-iturri gisa (Burke, 2005). Are gehiago, esparru akademikotik at, ikus-entzunezkoa herritar gehienen iturri nagusia bihurtu da gertaera historikoetaz jabetzeko (Rosenstone, 1997). Bada, orain, testuak aztertzeaz gain, iraganari buruzko informazioa ematen duen guztia aztertzen da. Martínez Gilek (2013) dio bi diziplina horiek "love story" erromantiko batean daudela, eta bertan ezarri direla harremanaren oinarriak: ezin zaio eskatu iraganean girotutako film bati erabat zehatza eta egiazkoa izatea, baizik eta, nolanahi ere, egiazalea. Eta, era berean, historia liburu bati ere ezin zaio eskatu entretenigarria eta arina izatea.

Historiaren eta zinemaren arteko harremanaz hitz egiterakoan, De Pablo aipatu beharra dago urte luzeak baitaramatza Gerra Zibilaren inguruko zinema garaikidea zein aintzinekoa aztertzen, batez ere, historiografiaren ikuspegitik helduta. Bere aburuz, harreman estua dago bien artean, funtsean bi alderditan: batetik, filmaren irakurketa historikoa (hau da, filmak iturri historikotzat hartzea, kultura-produktu izateagatik) eta, bestetik, historiaren irakurketa filmikoa, zinemaren adierazpideetatik abiatuta film batzuetan diskurtso historiko bat egitea (De Pablo, 2001). Ondorioztatzen duenez, liburu akademikoak baino jende askoz gehiagorengana iristen denez, zinemak eragina du historian, berau eraikitzeko gaitasuna baitu, gizartean eragiten duelako eta estereotipoak eta pentsamoldeak sortzen baititu.

Gauzak horrela, iragan hurbilari buruzko filmak aspalditik egin dira Espainiar Estatuan, baina mezua aldatuz joan da, gizartean eta politikan gertatu den bezala. Horrenbestez, diktadurako filmak eta gaur egungoak oso desberdinak dira mezuan eta, beraz, garrantzitsua da Espainiako zinemaren bilakaera ikustea XxI. mendea aztertzeko. Barrenetxea Marañonek (2012) hiru memoria desberdin sailkatu ditu garai politikoaren arabera: frankismoaren memoria ofiziala, Trantsizioaren oroitzapena eta egungo memoria ordaingarria. Bestalde, 2000. urtea baino lehenagoko ekoizpen kultural eta historiografikoak, frankismoan baino gehiago, Gerra Zibilean zentratu ziren (Aguilar Fernández, 2006). 80ko eta 90eko hamarkadetan kalitatezko ikerketa asko egin ziren arren, ia ez zuten eragin sozialik izan. Horregatik, zinema eta eleberria bezalako esparruek garrantzi handia izan dute Espainiako Estatuan memoria berreskuratzeko (Liikanen, 2015).

Gizarteak bezala, milurteko berrian zinemak 90eko hamarkadaren erdialdetik aurrera hasitako ibilbidean sakondu zuen eta, horrela, memoria historikoa landu duten filmen kopurua handituz joan da. Era berean, une horretan beste eremu batzuetan memoria historikoarekiko interesa piztu zen (kazetaritza, politika, zuzenbidea, historiografia...), eta, zehazki, Gerra Zibilaren eta diktaduraren ondorioe- 
kikoa. Emandako aldaketa soziala kontuan hartuta, ez da harritzekoa ekoiztetxeak gaiari buruzko filmak egiten hastea: zinema negozio bat da, eta zinemagileek, edozein ekoizlek bezala, jendearen nahiak eta joerak aztertu behar dituzte zer eskaini jakiteko.

Hala, ez dira gutxi azken urteotan memoria kolektiboa landu duten filmak: La lengua de las mariposas (José Luis Cuerda, 1999), El espinazo del diablo (Guillermo del Toro, 2001), Silencio roto (Montxo Armendáriz, 2001), La luz prodigiosa (Miguel Hermoso, 2002), Una pasión singular (Antonio Gonzalo, 2002), El viaje de Carol (Imanol Uribe, 2002), El lápiz del carpintero (Antón Reixa, 2003), Soldados de Salamina (David Trueba, 2003), Para que no olvides (Patricia Ferreira, 2005), El laberinto del fauno (2006, Guillermo del Toro), Las 13 rosas (Emilio Martínez Lázaro, 2007), La buena nueva (Helena Taberna, 2008), La mujer del anarquista (Peter Sehr eta Marie Noëlle, 2008), Los girasoles ciegos (José Luis Cuerda, 2008), Estrellas que alcanzar (Mikel Rueda, 2010), Pa negre (Agustí Villaronga, 2010), Balada triste de trompeta (Álex de la Iglesia, 2010), Ispansi! (Carlos Iglesias, 2010), La voz dormida (Benito Zambrano, 2011), Gernika (Koldo Serra, 2016), Un dios prohibido (Pablo Moreno, 2017), La higuera de los bastardos (Ana Murugarren, 2017), La trinchera infinita (Jon Garaño, Jose Mari Goenaga eta Aitor Arregi Galdos, 2019) eta Mientras dure la guerra (Alejandro Amenábar, 2019), besteak beste.

Zuzendari bakoitzak ikuspegi batetik heldu dio gaiari, eta ikuspuntu horren arabera garatu dute istorioa: ildo horretan, Silencio Rotok gerraostean Errepublika berreraikitzeko borroka antifrankistaren hurbilketa egiten du, alegia, makiaren ekintza. Hala ere, Armendarizek egiten duen hurbilketa hori ez da gerrillariei buruz egin den lehena; are gehiago, kultur ekoizpenaren zati handi bat makiei buruzkoa izan da (Ryan, 2014, 341. or.). Martinez Alvarezek (2012) bi garai bereizi ditu frankismoaren ostean makiari buruzko filmen ekoizpenean landutako ikuspegiaren arabera: Lehenengoan, Los días del pasado (Mario Camus, 1978), El corazón del bosque (Manuel Gutiérrez Aragón, 1979), Luna de lobos (Julio Sánchez Valdés. 1987), La guerra de los locos (Manuel Matji, 1987), Beltenebros (Pilar Miró, 1991) edota Huidos (Sancho Gracia, 1993) bezalako filmak egongo lirateke; bigarrenaren barnean, hurrengoak: El Portero (Gonzalo Suárez, 1999), Terra de canons (Tierra de cañones) (Antonio Ribas, 1999), You're the one (Una historia de entonces) (José Luis Garci, 2000), El año del diluvio (Jaime Chavarri, 2001), El embrujo de Shanghai (Fernando Trueba, 2002), Hormigas en la boca (Mariano Barroso, 2004), El laberinto del fauno (Guillermo del Toro, 2006), Entrelobos (Gerardo Olivares, 2010), Caracremada (Lluís Galter, 2010) eta La voz dormida (Benito Zambrano, 2011). Lehenengo garaian zinema posibilista gailendu zen, alegia, ahanzturaren bidez Trantsizioan akordioaren alde eta hausturaren aurka egin zuen ezkerraren ikuspegia, zeinean gertaera batzuk ekartzen dituen gogora baina irakurketa politikorik egin gabe. Bigarren aroan, aldiz, zuzendariek gertaeren gaineko jarrera argia erakutsi dute. Hots, Silencio roto azken testuinguru horretan sartu beharra dago. 
Autore batzuek jada Silencio roto filma aztertu dutela jakinik, lan honek ikuspegi berri batetik jorratu nahi du, aurreko ikerketen osagarri gisa. Barrenetxea Marañónek eta López de Maturanak (2017) Espainiako zinemagintzaren irudimenean makiak izandako aldaketa erakutsi dute Frankismoan ekoiztutako La paz empieza nunca (León Klimovsky, 1960) eta demokrazia garaiko Silencio roto alderatuz. Ondorioztatzen dutenez, lehenengoan espainiartasuna suntsitu nahi dutenen aurkako defentsa naturala frankismoa den heinean, bigarrenean intolerantziaren eta indarkeriaren inguruko gogoeta egitea proposatzen da, Klimovskyren manikeismo nabarmena gaindituz. Devenyk (2008) xxI. mendean gerrillaren inguruko kontakizunak hartutako garrantzia aipatzen du, denbora-tarte berdinean horri buruzko bi film estreinatu baitira, Armendarizena, eta La guerrilla de la memoria (Javier Corcuera, 2002), bai eta biek amankomunean dituzten ezaugarriak azaldu ere. Bestalde, Sánchez-Bioscak (2005) filmaren lekukotza-joeraren errealismoa azpimarratzen du; izan ere, Silencio Rotok lekukoen bidez lantzen du makia. Modu horretan, lekukoen ahotsak bide ematen dio Espainiako trantsizio demokratikoak ahanzturaren putzuan sartu zuen giza-bizipen baten ezagutzari. Eta, filmaren errealismoa da, hain zuen ere, Jünkek azpimarratzen duena. Bere esanetan, 40ko hamarkadako historikotasuna eta alteritatea murrizten ditu, eta forma ezagun eta kulturalki konbentzituetan aurkezten du; bestalde, substratu historikoaz jabetze horrek aukera ematen du «oroimenaren irudi» bihurtzeko, Espainiako memoria kulturalean makien historia sartzen laguntzen baitu.

\section{Metodologia}

Filmaren interpretazioa finkatu ahal izateko ikus-entzunezko ikuspegitik aztertua izan da, hausnarketa historiko sakona analisitik at geldituz. Era berean, artikulu hau ikerketa kualitatibo batetik aurkezten da, eta horren garapenean oinarri teorikoak erabili dira. Zinemaren berezitasunetik abiatuta, baliabide narratiboak eta estetikoak identifikatu dira, alferrikakoa bailitzateke edukirik eta esanahirik gabeko gramatika ezin hobea. Ikus-entzunezko teknika konplexu eta aberats batek istorio bat behar du ikus-entzulearengana iristeko, eragiteko eta identifikatzeko. Zineman istorio hori testu narratiboak eskaintzen du, film-testuan ${ }^{1}$ bihurtuta. Halaber, zineman, argumentuaren testu-gidoia egoteaz gain, filmazio-gidoia ere badago, planoak, eszenak, sekuentziak, soinu-banda eta abar jasotzen dituena. Bi gidoiek argumentu-hariari laguntzen diote, edukia aberastuz, osatuz eta irismena handituz. Beraz, analisi filmikoa egiteko, gertakarien kontakizunak — narrazioa — eta antzezpenak —eszenaratzea - hartu dira kontuan. Eraikuntza narratiboaren funtsa hiru elementu nagusitan oinarritzen da: pertsonaia, ekintza eta gatazka (Galán Fajardo, 2007). Horiek identifikatu eta aztertuz makiaren irudikapena ikertu nahi da, alegia, filmaren mezua.

\footnotetext{
1 Aguilar Fernándezek (1996) argi eta garbi definitzen du film-testua zer den: kausa-efektu erlazioarekin lotutako gertakari batzuk, leku, denbora eta espazio batean garatutakoak.
} 
Zinemak duen baliorik garrantzitsuena bere kontakizuna ikus-entzulea hunkitzean datza: bere sentimenduak pizten ditu bere zuntz sentikorra ukituz eta pentsamendua sorrarazten du. Horretarako, ordea, beharrezkoa da planifikatzea, sistematizatzea eta irudiarekin eta soinuarekin integratzea, eta horrek ahalbidetzen du ikus-entzulearengan eragitea. Hurrengo puntuetan, Silencio Roto filmaren kontakizunera, haren egiturara, zentzura eta efektuetara hurbiltzen saiatuko gara, ikus-entzunezko kodeekin batera, zinema benetan ikuskizun atsegin bihur dadin laguntzeko.

\section{Ahaztutakoen omenez}

Armendariz Silencio Rotorekin gerraosteko gertaerak kontatzen saiatu da, zehazki, galtzaileen eta emakumeen ikuspuntutik. Horretarako, zuzendariak gerrillaren gaiari heltzen dio makiaren bitartekarien bitartez, hau da, protagonista nagusiak mendian ezkutatuta zeuden gerrillarien laguntzaileak dira. Armendarizek erregimen frankistaren aurkako erresistentzian parte hartu zuten ahaztutako guztien omenez egin du filma. Hala, 1944ko udazkenean, 21 urteko Lucía (Lucía Jiménez) Pirinioetako herri batera itzuli da, Espainiako hiriburutik ihesi. Haurtzaroan bertan bizi izan zen, amarekin Madrilera joan aurretik. Aita, ordea, frankistek hil zuten gerran. Alabaina, Lucíaz gain, beste emakume askok ere badute paper garrantzitsua filmaren argumentuan, ahots aniztasun horri esker, gerra ostean herrian emakumeak nola bizi ziren adierazteko. Zuzendariak egitura zinematografiko zehatz batean oinarritzen du argumentua, pertsonaia horien guztien egiazkotasunetik abiatuta. Bigarren mailako argudio horiek dira, beraz, Silencio rotori aberastasuna eta egiazkotasuna ematen dizkiotenak.

Protagonistak bakea ezarrita zegoela uste duen arren, herri txiki horretan beste errealitate bat aurkitzen du: oraindik ere Francoren aurka borrokatzen diren pertsonak daude, mendian ezkutatuta. Hiritik etorri berriak borrokan jarraitzen dutenak bere ideiengatik miresten ditu eta, batez ere, beren balioengatik. Baina, laster jakingo du mendiak ezkutatzen duen errealitate gordina: horrenbeste maite duen Manuelek (Juan Diego Botto) mendira ihes egitea erabakiko du atxiloketa saihesteko, eta, horren bidez, Lucíak erresistentzia antifrankistaren alderdi garrantzitsu bat ezagutuko du. Herrian errepresio politikoa, isiltasuna, salakeriak eta izua baino ez ditu aurkituko. Hala ere, Manuelekiko duen grinari esker, inoiz garai hobeak iritsiko diren ilusioan eta itxaropenean tinko jarraitzen du. Gerra, beraz, ez da amaitu, eta, egoera honetan, armak utzi nahi ez dituzten familiei, emakumeei eta haurrei eragiten die nagusiki.

Hala, Silencio roto 1944ko udazkenean hasi eta 1948ko neguan amaitzen da. Tartean, makiak herria bereganatzea lortzen du, denbora tarte txiki batean bada ere. Nahita nahiez, antzekotasunagatik, ekintza honek Aran haranaren (Katalunia) hargunea gogorarazten digu, non makiak hainbat herri hartu zituen. Erasoak astebete baino gutxiago iraun zuen, eta porrota bikoitza izan zen: ezin zuten irrikaz nahi zu- 
ten Errepublika txikia ezarri, eta, uste zutenaren aurka, herria ez zen matxinatu. Baina Armendarizen xedea ez da ekintza hura azaltzea, haratago doa: galtzaileen bizipenak erakutsi nahi ditu. Horregatik, ahalik eta modurik errealistenean eta, gainera, modurik gordinenean islatzea izan da bere hautua. Horrela, protagonisten arteko elkarrizketek gidatzen dute filma.

\section{Korapiloa askatzeko oinarriak}

Silencio rotok aurkezten duen korapilo konplexu honen atzean, lau gai bereiz daitezke: harremanak, itxaropena eta etsipena, bidezkotasuna eta babes eza.

\subsection{HaRremanAK}

Pertsonaia nagusi gehienak senitartekoak dira, baina, harremanak sendoak izan arren, gerraren erruz bihurritzen dira. Harremanak oso garrantzitsuak dira, eta ez norberarentzat bakarrik, baita komunitatearentzat ere. Harremanak ondorioak dakartza. Filmaren lehen unetik antzeman daiteke, dituzten tratuen arabera, gizarteak modu batera edo bestera sailkatuko dituela. Hala, Lolak (María Botto) Lucíari ohartarazi dio etorri berriak erlazio estua duela gorri batekin (Gerra Zibilean nazionalek hil zuten haren aita), eta ez zaiola komeni herriko beste gorri batzuekin harremanetan jartzea, agintariekin arazorik ez izateko.

Arreta jarri behar da Lucíak garatzen dituen harremanetan, azken finean bera baita ikus-entzulea zuzentzen duena. Zentzu honetan, izeba Teresak (Mercedes Sampietro) bere iloba une oro gidatzen du zalantzazko mundu batean. Berak egiten eta esaten duenak berebiziko garrantzia du istorio osoa aditzeko. Eta, hark ematen dituen aholkuetatik, bada bat azpimarratu behar dena: "[...] Ez fidatu inortaz, Lucía, inortaz. Jarraitu bakarrik hemen [bihotza] barruan sentitzen duzunari, soilik horri». Begira hori bakarrik. Hori da Armendarizek film honetan igortzen duen mezu nagusia: politikaren gainetik giza faktorea dagoela. Zinema kritikari eta egile batzuen arabera, Lucíak ez ditu Teresaren aholkuak jarraitzen gerrillariei laguntzen dielako, hasieran izebak bere ilobari istiluetan ez sartzeko agintzen baitio. Hori berehalako ondorio okerra da. Sakonean aztertuz gero, Lucíak bere izebak gomendatutakoa hitzez hitz betetzen duela ikus daiteke: sentimenduei jarraitzea. Hala, Teresak don Hilario (Álvaro de Luna) errepublikanoari laguntzen dion bezala, Lucíak Manuel gerrillariari laguntzen dio. Biek bihotzaren taupadei jarraitzen diete. Ildo beretik mintzo da Teresa gerrillariei jaten ematen dienean: «Beren ideiengatik hiltzea ergelkeria da, baina gosez hiltzea bihotzgabekoa da».

Don Hilario ere protagonista nagusiaren erreferentea da, berak argitzen baitizkio frankismoaren aurkako borrokari buruzko zalantza guztiak. Pertsonaia hau 
erresistentziaren ideologoa da eta, horregatik, Lucíaren erreferentzia politiko eta intelektuala ere bada. Beraz, maisu ohiak Lucíari adierazten dio bidea batzuetan zalantzazkoa izan daitekeela, baina funtsezkoena bere atzean dauden ideiak direla.

Manuel, aldiz, makiaren isla da. Berari esker, protagonistak sasiarteak dakarren bizitza latza ezagutzen du. Hala ere, sufrimendua nagusitu arren, aurrera begira dago beti, etorkizun oparoaren zain. Bi maitale horien harremanean gertatzen diren gorabeheretan islatzen da Lucíak frankismoaren aurkako erresistentziarekiko duen uneko jarrera.

Gainera, protagonistak harreman garrantzitsua dauka bando nazionaleko emakume batekin. Nahiz eta bakoitzak kontrako posiziotik ekiten dioten, begi bistakoa da bien arteko errespetua. Aktoreen kokapenaren bidez, Armendarizek argi eta garbi azaltzen du bi pertsonaia hauen posizionamendua: Sole (María Vázquez) beti dago leihoaren goialdean, Lucía lurrean dagoen bitartean; Solek errealitate gordina bere etxeko altueratik babestuta ikusten du (1. irudia), beraz, ez dio zuzenean eragiten; Lucíari, aldiz, errealitate honek zuzenean eragiten dio eta horregatik dago lurrean (2. irudia). Filmaren amaieran, makiek Soleren senarra hiltzen dute, eta Sole lurrera jaisten da, errepresioak ere bete-betean jo baitu (3. irudia). Oraingo honetan, Lucía da etxe barruan babestuta dagoena (4. irudia).

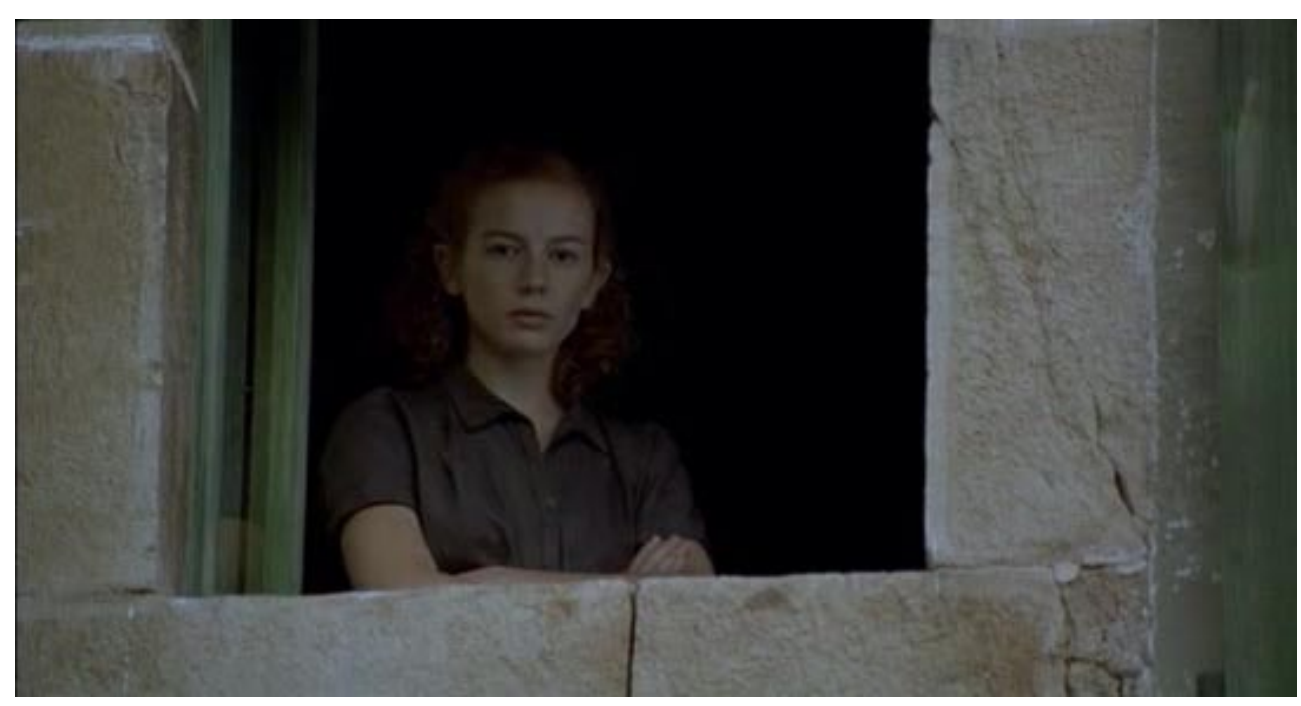

1. IRUDIA

Sole errealitateari begira etxean babesturik 


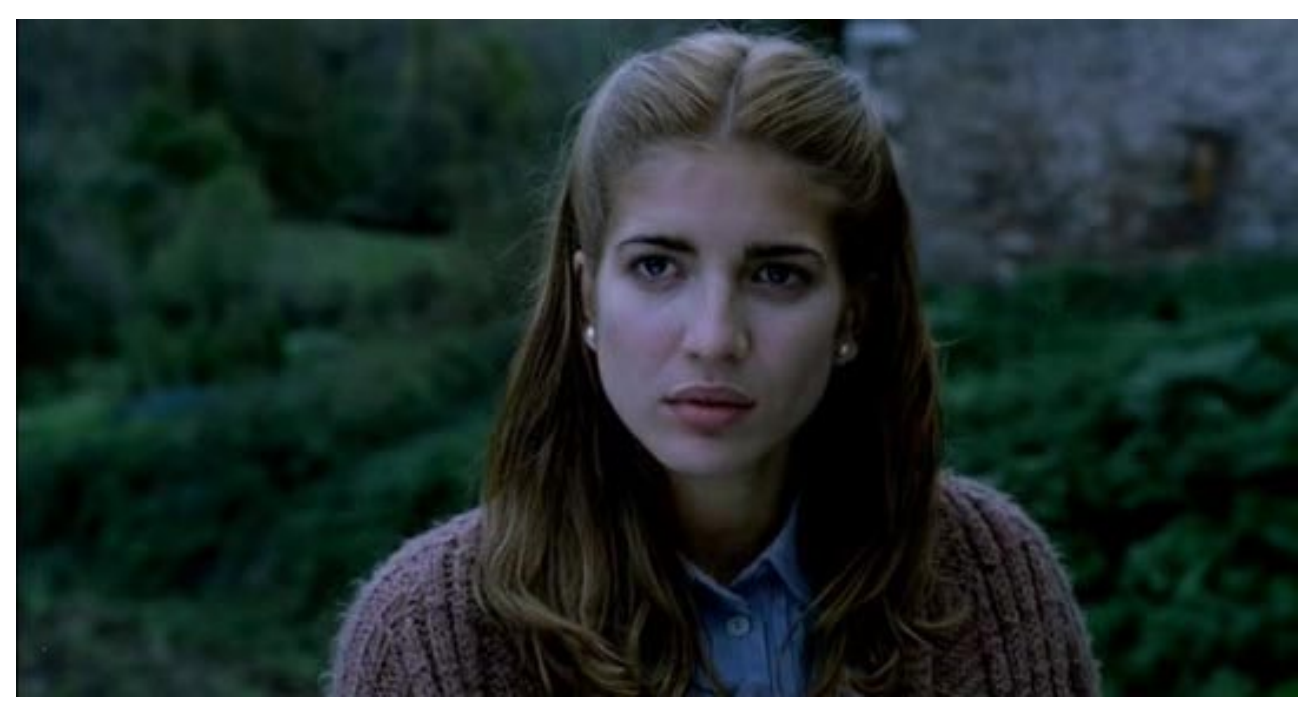

2. IRUDIA

Lucía lurretik Soleri begira

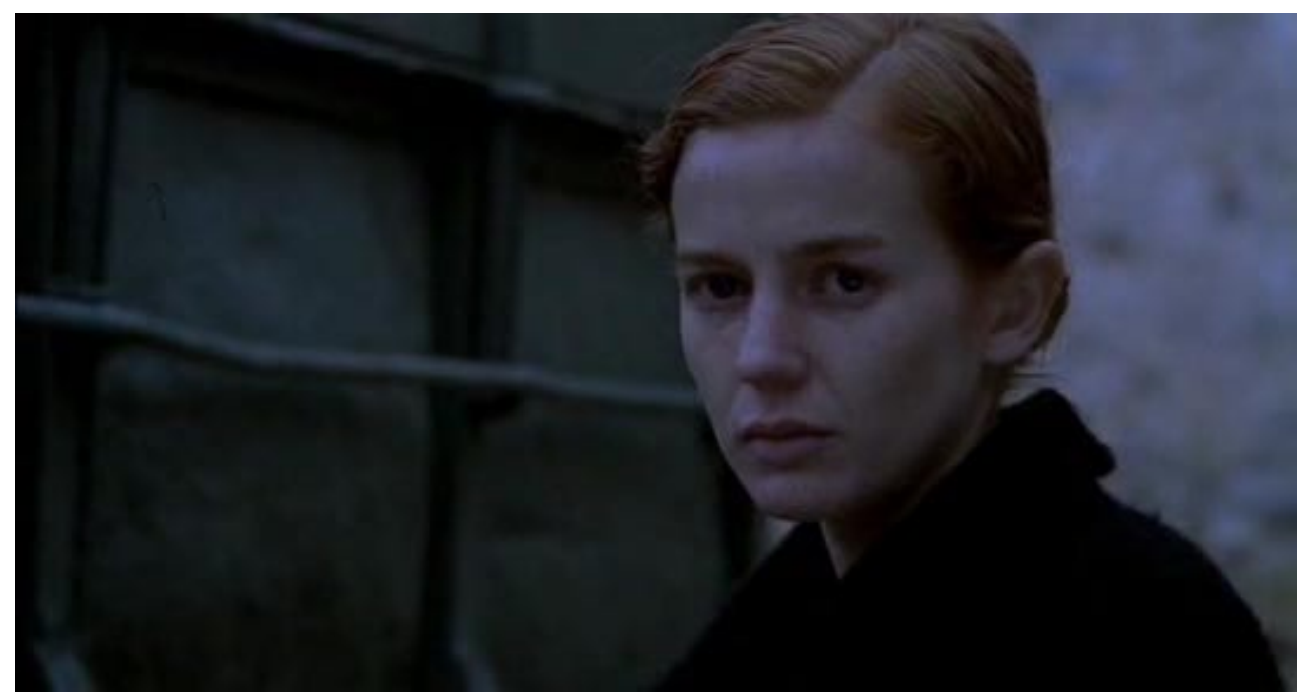

3. IRUDIA

Sole lurrera jaitsi da, errealitatera 


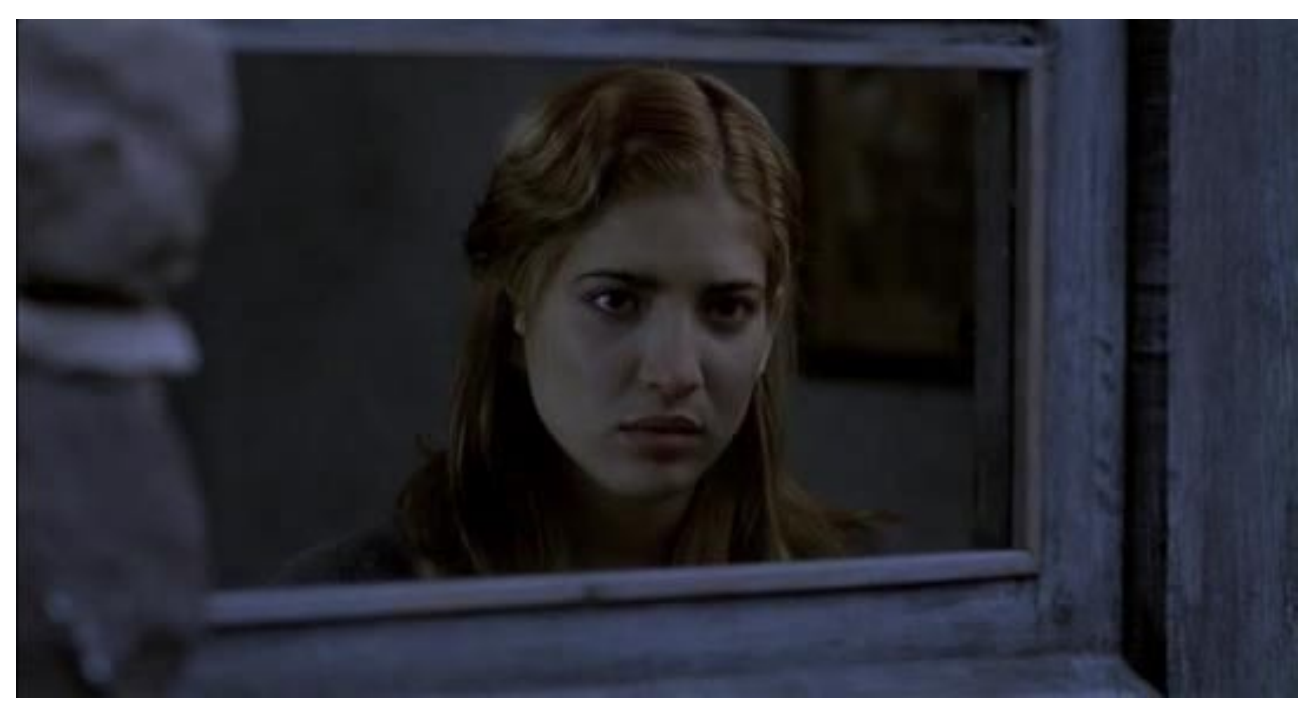

4. IRUDIA

Lucía etxean babestuta

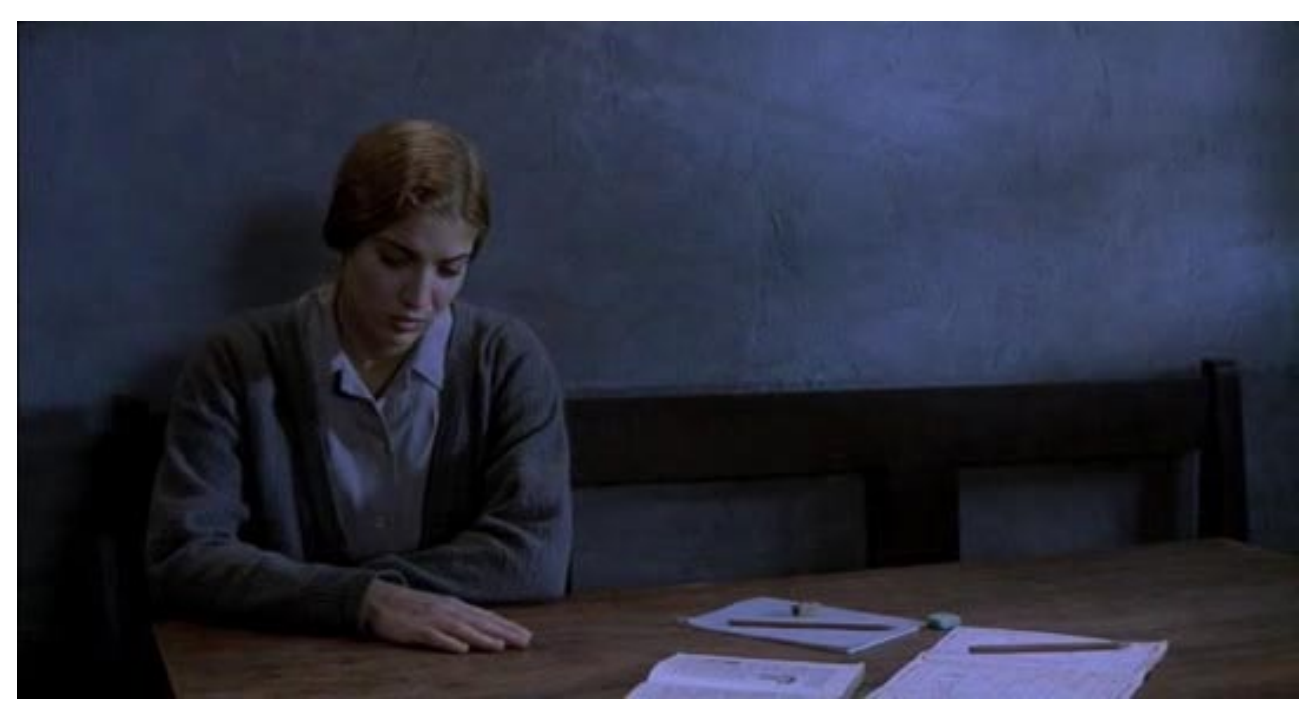

5. IRUDIA

Lucía tabernan dagoen azken aldian

Bere senarra hil aurretik Sole ez zela zoriontsu antzeman daiteke. Herritarrek bakartuta daukate, herriko kaboarekin (Kandido Uranga) ezkonduta dagoelako. Ba- 
kardade kontzeptu horretan sakontzeko, zuzendariak «Soledad» izena jarri dio pertsonaiari. Hala ere, Solek ez du bat egiten erregimen frankistak eta, bereziki, Guardia Zibilak egiten duten errepresioarekin. Pertsonaia hau oso garrantzitsua da: funtsean, Armendarizek transmititzen duen ideia da emakumeak direla beti gehien sufritzen dutenak. Eta ideia hori behin eta berriz agertzen da filmak irauten duen 110 minutuetan.

Azkenik, Lucíak duen harremanik sendoena alaba jaioberriarekin daukana da. Lucíaren alaba etorkizuna da. Horri esker, Lucíak behin betiko uzten du iragana, aurrera egiteko. Horregatik joan zen, hain zuzen ere, azken aldiz herrira 1948ko neguan. Izebak zertarako itzuli den galdetzen dionean, Lucíak argi uzten du: itzuli beharra zegoen, horixe sentitzen zuen bihotzean. Horrenbestez, protagonista ez da herrira itzuliko: maite dituen guztiak hilda, eta Lolarekiko adiskidetasuna hautsita, ez dago itzultzeko arrazoirik. Joan aurretik, Lolarekin tabernan dagoen bitartean, samurtasunez laztantzen du tabernako mahaia (5. irudia). Erabakia hartuta dago, etorkizunari begiratzeko unea iritsi da. Era berean, alabak filmak jorratzen duen bigarren gaia adierazten du: itxaropena eta ilusioa.

\subsection{ITXAROPENA ETA ETSIPENA}

Filmean hiru etapa zehatz agertzen dira, oso nabarmenak eta oso ezberdinak: 1944ko udazkena, 1946ko uda eta 1948ko negua. Lehen garaian erresistentziaren aurkezpena egiten da; bigarrenean, berriz, ilusioa eta itxaropena nagusitzen dira gerrillariak menditik jaitsi eta herria hartzen dutenean; eta hirugarren garaian, pertsonaia nagusiak erabat etsita daude. Azken denbora-tarte horretan gerrillariek ez dute Errepublika berrezartzeko borrokatzen, mendian bizirauteko baizik. Montielen arabera (2001), ez du zentzu zinematografiko handirik garai bakoitzeko paisaiaren argazkia erakusteak, baina esan behar da, hain zuzen ere, une bakoitzean erakutsi nahi den sentsazioaren isla argiak direla.

Azken bi garaiei erreparatuz gero, bien arteko aldea oso nabarmena da. Itxaropena eta ilusioa udan agertzen dira, negua etsipena den heinean. Kolore nagusietan ere desberdintasunak nabarmenak dira: itxaropena adierazteko, kolore biziak (6. irudia); etsipenerako, kolore ilunak (7. irudia). Hori soinekoetan ere ikus daiteke: lorez adierazitako itxaropena; etsipena, kolore bakar eta ilunez. Lucíak eta Lolak, gainera, orrazkera desberdina dute azkenaldian: ilea aske eraman beharrean, bilduta daramate. Tabernako giroan ere islatzen da bi garaien arteko aldea: bigarren atalean taberna jai giroan dago; azkenekoan, zuzendariak taberna erabat hustuta erakusten du. Hau guztia garrantzitsua da filma edukiz betetzeko. Horrela, film osoan gertatzen den bezala, garai bakoitza Lucíaren eta Manuelen arteko maitasun istorioan islatzen da: ez da kasualitatea Lucía haurdun geratzea filmaren unerik alaienean. 


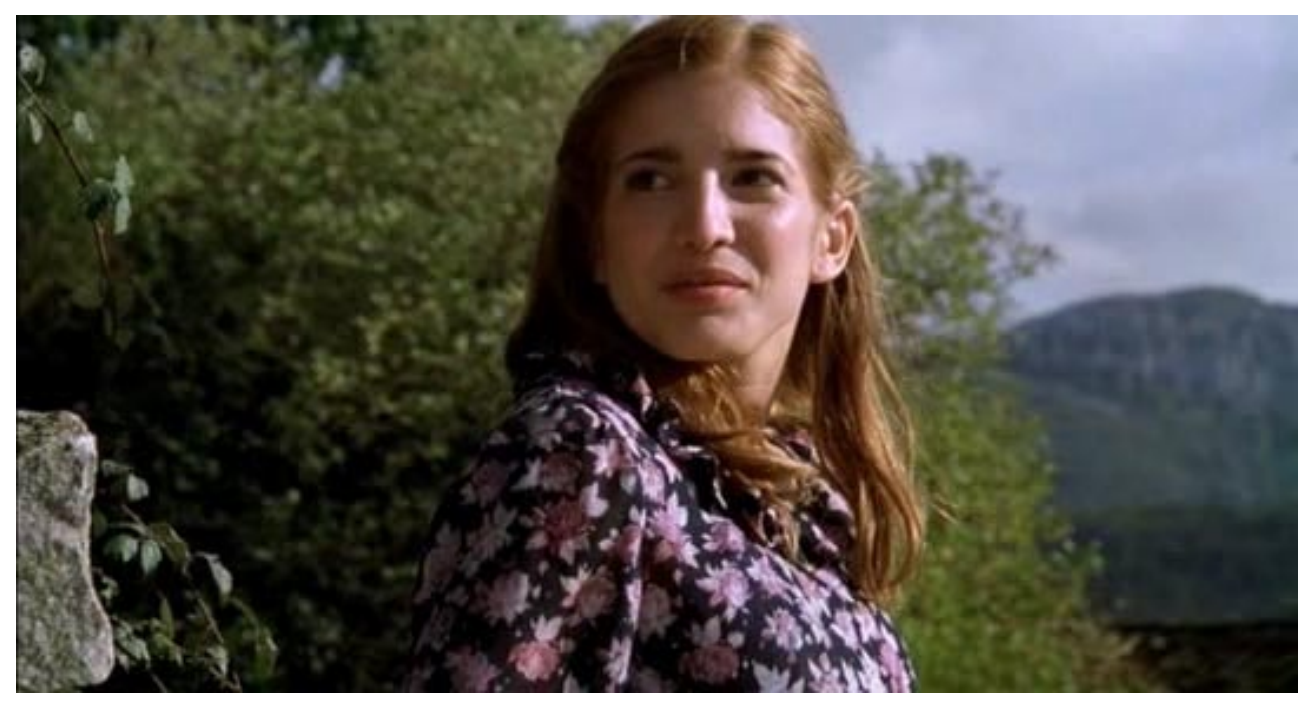

6. IRUDIA

\section{Kolore biziak}

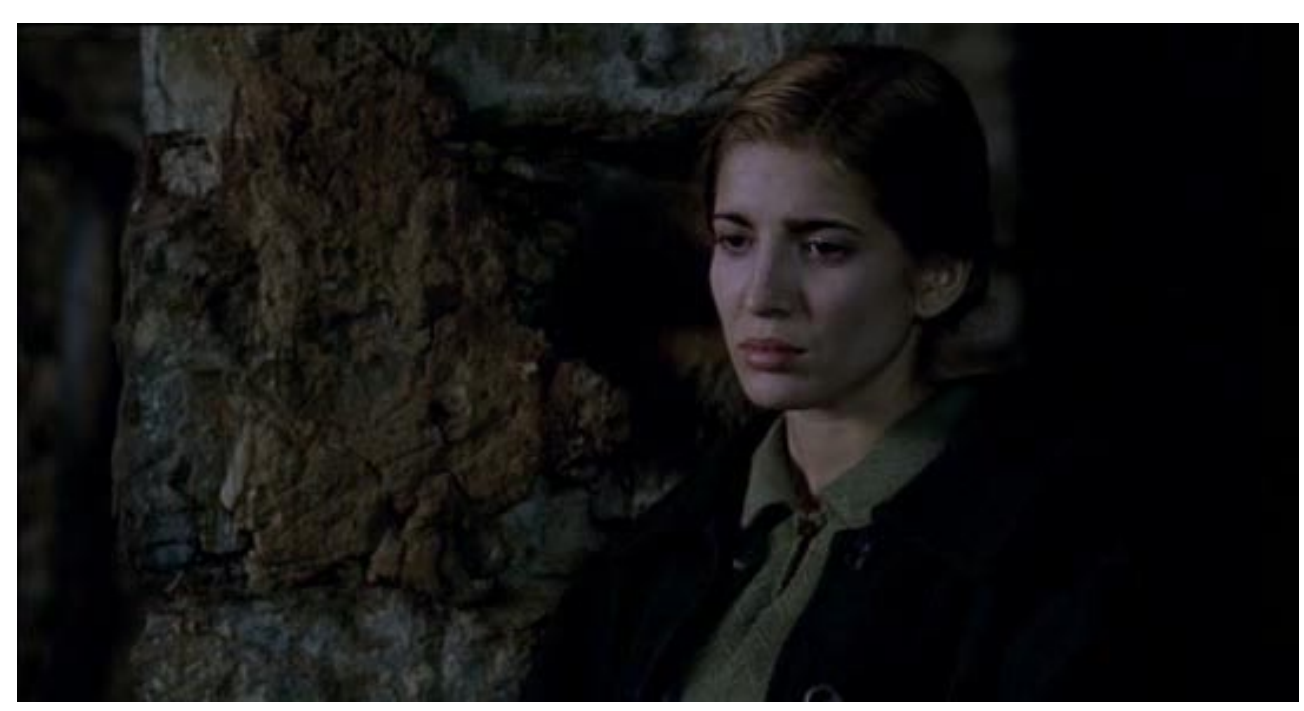

\section{IRUDIA}

Kolore ilunak

Aipatutakoaz gain, hainbat pertsonaiek itxaropena islatzen dute. Bi rol nabarmentzen dira: don Hilario eta Genaro (Joan Dalmau). Bi pertsonaia hauek dira ilu- 
sioaren adierazle nagusiak: lehenak itxaropena sortzen du, bigarrenak, berriz, itxaropena du eta ez du inoiz galduko. Genaroren semea, Miguel, Gerra Zibilean erail zuten arren, bere aitak uste du bizirik jarraitzen duela Frantzian borrokan don Hilariok idatzitako eskutitzei esker. Ohar guztiak itxaropentsuak dira: naziak akabatzen ari direla, Mundu Gerra laster amaituko dela eta, ondoren, aliatuek Espainia faxismotik askatuko dutela, berehala itzuliko dela bere gurasoen etxera, baina aurretik injustiziari aurre egin beharko diola, etab. Erresistentziaren garrantziari buruzko mezuak funtsezkoak dira makiak irudikatzeko. Gerrillarien (eta don Hilarioren) idealismoak «injustizia eta zapalkuntza amaitzea» eta "mundu hobe baten alde borrokatzea» adierazten ditu. Beraz, don Hilario bi ardatzetan mugitzen da: alde batetik, lehen aipatu bezala, erresistentziari itxaropena sortarazi nahi dio; bestetik, pertsonaia hau idealismoaren adierazpena da.

Ilusioaren hirugarren adierazlea Manuel da. Pertsonaia honek erresistentziaren itxaropena irudikatzen du. Beti irribarretsu, egoerarik zailenetan ere bere irribarrea erakusteko prest dago, egoera noizbait itzuliko delakoan. Armendarizek Manuelen alde hori nabarmentzea erabaki du, hau da, gerrillaria izan arren, bere irudikapena gehiago oinarritzen dela ilusioan, erresistentzian bertan baino. Behin baino gehiagotan azaltzen du berak ez dakiela gerraren egoera orokorraz, baina borrokan jarraitzeko ilusioa duela, agintariek laster erresistentziaren garaipena iritsiko dela zin egiten baitute.

Makiak nazioarteko potentzietan jarri zuen itxaropen guztia, nazismoa garaitu ondoren Francoren aurka borrokatuko zirelakoan. Baina hori ez zen horrela izan eta, aitzitik, Francori gero eta aintzatespen handiagoa eman zioten, makiaren gainbehera eraginez. Hori guztia filmean islatzen da, nazioarteko egoerari behin eta berriz erreferentzia eginez. Itxaropena nagusi den atalean, makiak aliatuek laguntza emango diotela uste du eta, nazioarteko komunitateak bizkarra ematen dionean, etsipena nagusitzen da. "Eutsi egin diogu gure kausaren alde egingo zutelakoan, baina faxistek baino gehiago izutzen ditugu», dio Manuelek. Armendarizek, beraz, herriaren etsipena ere azaltzen du. Bere adierazpenik gordinena filmaren hirugarren atalaren aurretik azaltzen da, ondoren etorriko denaren aurrekari gisa: Rosariok (Alicia Sánchez) bere buruaz beste egiten du. Zinean, literaturan eta bizitzan, suizidioa etsipenaren adierazpenik basatiena da. Batek bere buruaz beste egiten duenean, erabat etsita dagoelako eta bizitza horri uko egiten diolako da. Beraz, Silencio Rotok gerrillarien arteko etsipena ez ezik, hein handi batean, herritarren artean gertatzen dena ere islatzen du.

Filmaren azken zatian erabat aldatzen da pertsonaia nagusien izaera. Izeba Teresa ez da hain adeitsu agertzen ilobarekin. Lola guztiz itzalita dago: maite zituen guztiak hilda daude (ama, aita eta Sebas...), eta aspalditik Manuel nebari buruz ezer ez dakien arren, Lucíari argi uzten dio berarentzat denak hilda daudela. Ahazteko gogoa da hori. Lolak aipamen zuzena egiten die Espainiako Estatuan 
ahanzturaren alde egin zutenei. Baina pertsonaia hau ez da bakarra, Teresak ere ahazteko gogoa erakusten baitu. Manuelek ere itxaropena galdu du; Lucíak egiaztatzen du guardia zibilek irribarrea ostu diotela gazte distiratsuari. Manuel etsita dago hil aurretik: «Cago en Judas! Kendu egin didate [irribarreari buruz]. Ikusten?». Bere aurpegiak islatzen duenak ez du zerikusirik ordura arte transmititzen zuen distirarekin.

Filmaren amaieran, etsipenak ia guztia bereganatu duen arren, itxaropen txiki bat dago: Lucíak Genarori bere semearen gutunak bidaltzen jarraituko du (don Hilariok hil arte egin zuen bezala), hau da, ilusioa mantentzen jarraituko du. Lucía herritik irteten den bitartean, ortzadar bat ikusten da negu ilun horretan, oraindik itxaropen handia ematen duena (8. irudia). Udaberria dator, horrek duen zama guztiarekin: bizitza berria, eguzkia, egun argiak eta luzeak...

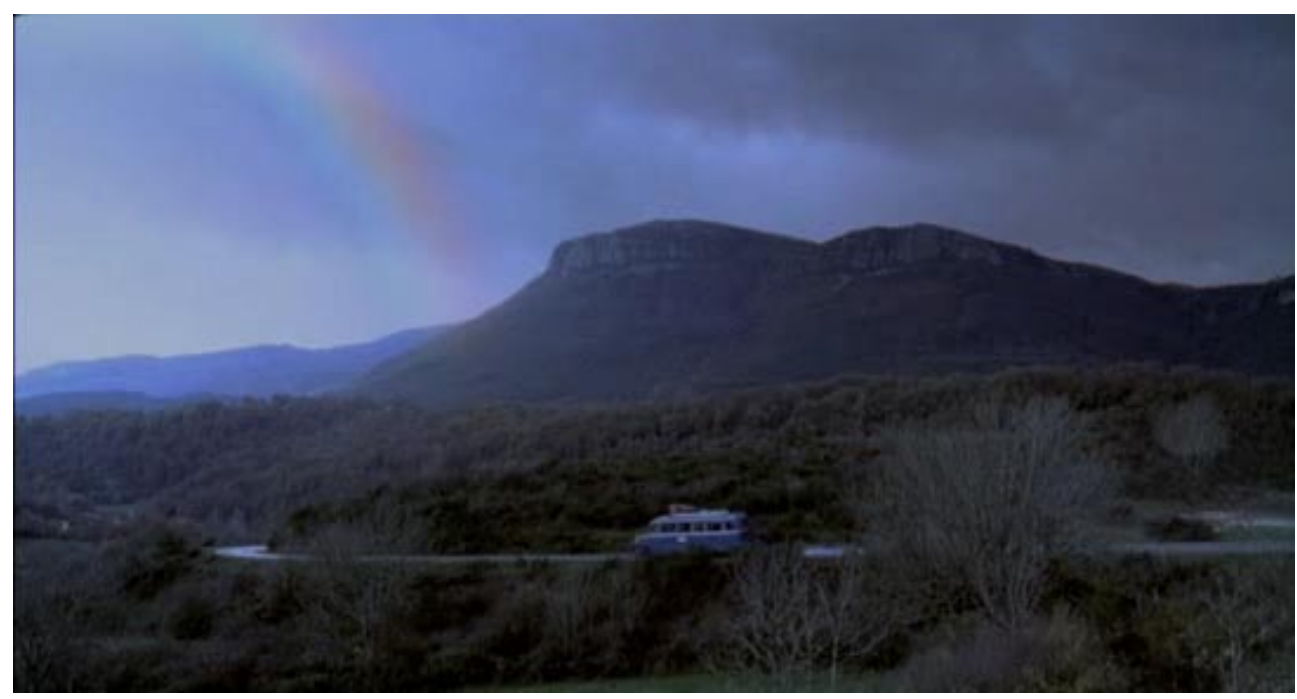

8. IRUDIA

Itxaropen zantzuak

\subsection{Bidezkotasuna}

Filmaren hirugarren ardatza bidezkotasuna da. Zer da justua? Silencio roto hilketez, zalantzaz, itxaropen faltsuz, garaipenez eta porrotez beteta dago, baina hausnarketa sakona ere aurkezten du. Horregatik, makiaren ikuskera aldatu egiten da gertaeren arabera: hasieran heroiak izan arren, filmak aurrera egin ahala, heroitasuna desmitifikatu egiten da. 
Filmaren hasieratik argi dago nork ezartzen duen justizia. Agintari frankistek mendekuz eta gorrotoz beteriko justizia ezarri zuten gerraosteko lehen urteetan. Guardia Zibilak herritarren aurka egiten zituen errepresioa eta mespretxuak film osoan ikus daitezke. Don Hilariok, adibidez, debekatuta dauka maisu izatea eta, urte luzez kartzelan egon ondoren, pobreziara kondenatzen dute. Indarkeriak aurpegi asko ditu eta Armendarizek hori erakutsi nahi izan du. Horregatik, filmean ez dira agertzen pertsonaia oso onak eta zintzoak eta oso gaiztoak eta maltzurrak direneko irudi absolutuak. Onak ere badu alde negatiboa. Hala ere, filmean argi eta garbi adierazten da nortzuk diren onak eta nortzuk gaiztoak.

Hainbat autorek diote Armendarizek bata bestearekin parekatzen dituela, alegia, erregimen frankista eta erresistentzia antifrankista txanpon beraren bi aldeak direla. Baina hori ez da horrela. Lehen aipatu bezala, zuzendariak manikeismotik ihes egin nahi izan du, eta, horregatik, ez du erregimen faxista maltzur baten aurrean erresistentzia idilikoa islatu nahi izan. Oreka bilatu du eta, horretarako, bien arteko hurbilketa egiten du, baina inoiz ere ez parekatuz. Erregimenak indarkeria fisikoa eta psikologikoa erabiltzen du etsaia gainditzeko. Rosario eta Lola dira adibiderik argienak. Lehenengoa indarkeria fisikoaren adibidea da hasieran, torturak jasaten baititu, eta, azkenik, indarkeria psikologikoak bere burua urkatzera bultzatzen du. Lolak, bere aldetik, beste ibilbide bat egiten du: gerrillarien lotura izatetik, filmaren amaieran, erregimena onartzera iristen da (erabat argitzen ez den arren, salatzaile frankista bihurtzen da). Bi kasuetan, frankistek irabazten dute.

Beraz, Guardia Zibilaren indarkeria oso agerikoa da. Aipatutakoaz gain, sarjentuak (Jordi Bosch) Sebas artzaina (Ruben Ochandiano) errizino olio botila osoa edatera behartzen du birao egiteagatik, edo tenienteak (Joseba Apaolaza) odol hotzean exekutatzen du gerrillari bat herriko plazaren erdian bere emaztea fusilatzeko agintzen duen bitartean. Tenientearen krudeltasuna filmaren amaieran nabarmentzen da Manuel eta Teresa fusilatzen dituztenean eta Lucíaren sufrimenduaz gozatzen duenean. Ez da justizia kontua, haratago doan gorrotoa baizik. Eta gorroto hori sistematizatuta dago, Manuel eta Teresa exekutatu aurretik, tenientearen atzean Francoren irudia duen enkoadraketan ikus daitekeen sekuentziak adierazten duen bezala (9. irudia).

Filmean bi pertsonaia baino ez dituzte hiltzen odol hotzean kameraren aurrean: lehena, lehen aipatu bezala, tenienteak gerrillari bat hiltzen duenean plazaren erdian, eta bestea, Antoniok (Ramon Barea) Guardia Zibilaren kaboa hiltzen duenean menditik ihes egin aurretik. Hor dago bien arteko hurbiltasuna, Armendarizek bilatzen duen oreka. Matxinoek, aldiz, gauzak desberdin egiten dituzte: frankistek ez bezala, gerrillariek indarkeriaren erabileraren zilegitasunean sakontzen dute: zer den bidezkoa eta zer ez. Erregimenak ez du zalantzarik errepresiorik bortitzena erabiltzeko. Horixe da, hain zuzen ere, bien arteko aldea. Matíasek (Helio Pedregal) eztabaida mamitsua dauka gainontzeko protagonistekin: gerrilariak Cosme (Pepo Oliva) exe- 
kutatu nahi du berehala, epaiketarik gabe, salatariei eskarmentua emateko. Hala ere, don Hilario guztiz kontra agertzen da. Eztabaidaren erdian, Lucíak adierazpen esanguratsua ekartzen du: «Jendea konbentzitzea da gurea, ez inposatzea eta izutzea faxistak bezala». Eta erresistentziak hausnarketa horretan dihardu film osoan zehar. Makiak epaiketen bidez ezartzen ditu zigorrak; Guardia Zibilak, ez. Matías, beraz, zuzendariaren bi indarkerien arteko hurbilketa litzateke. Horregatik, ez da kasualitatea bere hiltzaileak gerrillariak izatea eta ez guardia zibilak.

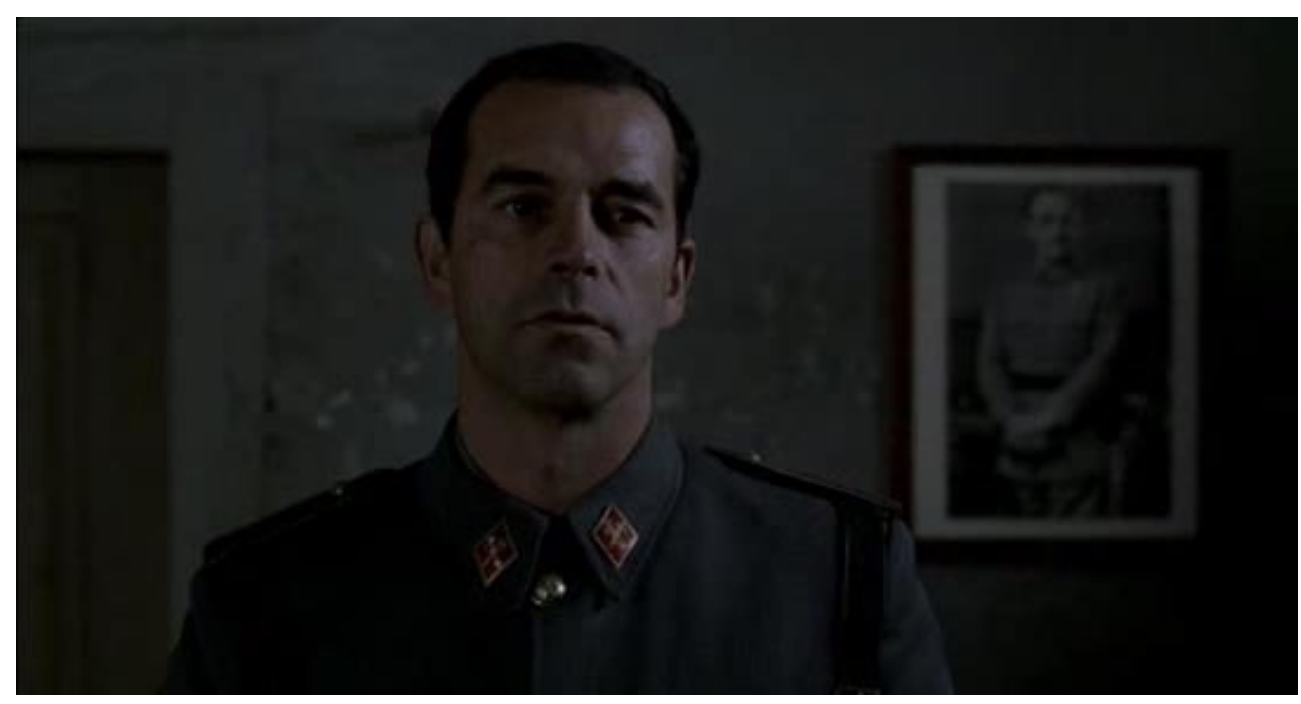

9. IRUDIA

Errepresioan oinarritutako sistema. Tenientea eta Franco plano berean

\subsection{BABES EZA}

Silencio roton inor ez dago salbu. Beste behin ere, Teresak horren gakoa emango dio Lucíari inorekin ez fidatzeko aholkatzen dionean: «Ez fidatu inortaz, Lucía, inortaz». Segurtasunik gabe, pertsonaia guztiak saiatuko dira hori lortzen: Manuel eta Matías, adibidez, mendian babesten dira; don Hilariok urteak eman behar ditu Teresaren etxeko atikoan ezkutatuta; Lucía hirira itzultzen da bere alaba jagoteko; Antoniok kaboa hiltzen du gerrillariak harrapatu ez ditzaten; Cosmek erresistentziaren loturak salatzen ditu, mehatxu egin berri dioten «sasikume» horiek hiltzeko; eta Teresa, arrazoi ezezagunengatik, Cosme frankistarekin ezkontzen da, don Hilario errepublikanoarekin ezkondu beharrean, honekin harreman estuagoak zituen arren.

Erregimena bera ere ez dago salbu. Bat-batean, makiak herria hartu eta ordena berria ezartzen du sarjentua exekutatuz. Are gehiago, pelikularen lehen bi ataletan 
badirudi aliatuek Franco uzkailiko dutela II. Mundu Gerra amaitzean. Irratiak ere, Francori egun gutxi geratzen zaizkiola ohartarazten du. Horrenbestez, frankismoaren aurkako erresistentzia eta, batez ere, bere ingurukoek dute babes txikiena; baina frankistak ere ez daude seguru. Cosme bera ere ez dago bere etxean salbu, eta, aukerarik onenean, hil ala biziko epaiketa egingo diote frankisten kolaboratzaile izateagatik.

Atal honetan nabarmendu beharreko rol bat dago: salataria. Salatariak, salaketak eta ondorioak dira, egin-eginean ere, filmaren harri triangeluarra. Ikus-entzunezkoaren hasieran, ustez, idazkariaren seme Alfredok Manuel salatu, eta mendira ihes egitera behartzen du. Horrela, zuzendariak garai hartan oso ohikoa zen salatzailearen irudia aurkezten du. Edonor izan daiteke salataria, ikus-entzuleari babes ezaren sentipena helaraziz. Hala, herriko plazan Alfredok tenienteari emandako informazioak, Rosariok bere buruaz beste egitea eragiten du eta, aldi berean, haren aurkako atentatua dakar.

Gerra horretan, bi aldeek erabilitako estrategia aurkariaren laguntzaileak suntsitzea da. Eta nortzuk ziren urgazleak? Herritarrak. Batzuk Guardia Zibilaren aldeko salatariak ziren, eta beste batzuk makiaren laguntzaileak. Beste behin ere, inor salbu ez dagoeneko ideia. Gainera, orokorrean, herrian emakumeak baino ez dira geratzen, gizonek mendiak eskaintzen duen babesaren bila ihes egiten duten bitartean. Horregatik, emakumeak harrapakin errazak dira. Senarrak eta semeak ihes egin ondoren, Rosariok guardia zibilen mendekua ordaindu behar du; beste bandoan ere, Solek bere senar guardia zibilaren hilketa jasan behar du; eta Teresari, nolabait erdibidean dagoenari — senarra frankista du eta lagun mina, antifrankista-, mina pairatzea ere egokitzen zaio. Teresa jabetzen da errealitate krudel horretaz, eta hala adierazten dio ilobari: «Zergatik sufritzen dute beti emakumeek gehiago?». Ildo beretik, Lucíak Soleri ea emakumeak nork errespetatuko dituen galdetzen dio: «Eta gu nork errespetatzen gaitu, e? Nork?». Mezu hau behin eta berriz errepikatzen da filmean. Adibidez, Matíasek epaiketarik gabe eskarmentua egin nahi duenean Rosariok gerrillariari ohartarazten dio emakumeak babesik gabe geratuko direla. "Zuentzat erraza da eskarmentuak ematea: eman eta desagertu egiten zarete. Eta gu zer? Zer gertatuko da gurekin alde egiten duzuenean?». Bi gertaera izan ziren funtsezkoak makiaren gainbeheran. Alde batetik, II. Mundu Gerraren osteko Gerra Hotzak nazioartearen babesa galtzea erakarri zuen, gerrillariak bizirauteko baino ez borrokatzera bultzatuz. Bestetik, Gerra Zibila amaitu bezain laster, militarrek eta guardia zibilek oldartuen aurkako uxaldi basatiak antolatu zituzten. Baina hauek alferrikakoak ziren eta oso gutxitan lortzen zuten iheslariak harrapatzea. 40ko hamarkadaren erdialdean, ordea, Erregimenaren estrategia aldatu zen eta iheslarien aurka egin beharrean, zeharka, senideak eta auzokoak zapaltzeari ekin zion. Honela hasi zen izuaren hirurtekoa bezala ezagutzen den aroa (19471949). Hau da, Armendarizek argi utzi nahi izan du nortzuk sufritu zuten gehien gerraostean: emakumeak. 
Lehen aipatu bezala, Teresak «ez zaitez inortaz fio» esaten du, eta zuzendariak amaierara arte mantentzen du egia borobil hori. Filmaren azken zatian, Lucía Genaroren etxera igotzen den azken aldian, gerrillari antza duten guardia zibilekin topo egiten du bidean. Orduan, Juanak (Asuncion Balaguer) onartzen du ezin dela inorekin fidatu: «Bada, bai. Orain, guardiak mendikoak bezala mozorrotzen dira. Orain ezin zara inorekin fidatu. Ezta ezagunekin ere». Eta hori da filmaren amaiera: ezagun batek Teresa eta don Hilario salatuko ditu. Argitu ez arren, zantzu guztien arabera, Lolak bere lagunak salatu ditu.

\section{Ondorioak}

Montxo Armendarizek ez du jarrera ideologiko argia baztertzen, baina errealitatearen konplexutasuna onartzen du; horregatik, Silencio Rotoren bidez, gerran biktimak eta borreroak bi aldeetan daudela adierazten du.

Irabazle eta galtzaileekin osatutako gizarte batean, emakume babesgabeak isilpean jasaten zituen irainak, isekak eta jazarpenak. Funtsean, hori da, filmaren mezu nagusia, erresistentzia etikoaren zentzuari buruzko hausnarketa sakona egiteaz gain. Ahots isildu horien bozgorailua izan nahi du Silencio rotok, izenburuak berak dioen moduan, urte luzeak iraun duen isilunearen haustura.

Mezu nagusia hori izanik, pelikulan makiaren ibilbidea jasotzen da. Horretarako, makian parte hartu zuten pertsonekin hitz egin du zuzendariak, eta hori nabaritu daiteke irauten duen bitartean. Aran bailararen aurkako erasoa gogora ekartzen duen arren, filmak, xehetasunez betea, ez du hori erreproduzitzeko helbururik. Besteak beste, urteak ez datoz bat. Filma haratago doa, makiaren ibilbidea eta garaiko testuinguru sozial eta politikoa ulertzeko gertakari garrantzitsuenak errespetatzen ditu.

Filmak iradokitzen duenez, une horretan auto-suntsitze bide bat hasi zen, gerrilla desegiten lagundu zuena, makiaren jarduerak eragin zuzena baitzuten haien senide, lagun eta laguntzaileengan. Gerrillarien porrot lazgarriak ikuslearen eta pertsonaien sufrimenduaren arteko identifikazio emozionala errazten du. Errepresioaz gain, pelikulak garai horretan ezinbestekoa bilakatu zen salatarien irudipena ematen du, Alfredo eta Lolaren bitartez. Azkenik, Silencio roto ez da garai horretara mugatzen, baizik eta beranduago izan ziren jarrerak ere adierazten ditu, alegia, ahanztura. Teresa eta Lola ahanzturaren isla dira, Trantsizioan eta demokraziaren lehenengo urteetan elite politikoan nagusitu zen jarrera. Bada, Armendarizek guzti hori fikzio batean zehatz eta mehatz azaltzea lortu du. Horregatik, filma informazio iturri ona da garai hura ulertzeko. 


\section{Erreferentzia bibliografikoak}

Aguilar Fernández, P. (1996). Memoria y olvido de la Guerra Civil española. Madril: Alianza Editorial.

Aguilar Fernández, P. (2006). La evocación de la guerra y del franquismo en la política, la cultura y la sociedad españolas. In Juliá, S. (ed.), Memoria de la guerra y del franquismo, 279-317. or. Madril: Taurus.

Barrenetxea Marañón, I. (2012). Cine, represión y Memoria Histórica. In A. Ibarra Aguirregabiria (ed.), No es país para jóvenes. III Encuentro de Jóvenes Investigadores en Historia Contemporánea. Granada: Instituto Valentín Foronda. Hemendik eskuratua: https:// dialnet.unirioja.es/descarga/articulo/4721523.pdf

Barrenetxea Marañón, I. eta López de Maturana, V. (2017). El maquis a contraluz: La paz empieza nunca (1960) frente a Silencio roto (2001). In M. G. Camarero Gómez Árbol académico eta F. Sánchez Barba (ed), V Congreso Internacional de Historia y Cine: Escenarios del cine histórico, 299-314 or. Madril: Universidad Carlos III. Hemendik eskuratua: https://e-archivo.uc3m.es/handle/10016/24740

Burke, P. (2005). Visto y no visto. El uso de la imagen como documento histórico. (De Lozoya, T. itzul). Bartzelona: Cultura Libre.

De Pablo Contreras, S. (2001). Cine e historia: ¿La gran ilusión o la amenaza fantasma? Historia contemporánea, 22. zenb, 9-28 or. Bilbo: UPV/EHU.

Deveny, T. (2008). Una nueva perspectiva sobre los maquis: Silencio roto y la guerrilla de la memoria. Quaderns De Cine, (3), 45-55. doi:10.14198/QdCINE.2008.3.05

Galán Fajardo, E. (2007). Fundamentos básicos en la construcción del personaje para medios audiovisuales. Revista del Ces Felipe II, 7. zenb. Madril: Centro de Estudios Superiores Felipe II. Hemendik eskuratua: http://www.cesfelipesegundo.com/revista/articulos2007b/ElemaGalan.pdf

Gaudrealult, A. eta Jost, F. (1995). El relato cinematográfico. Cine y narratología. Bartzelona: Paidós Ibérica.

Juliá Díaz, S. (2003). Echar al olvido: Memoria y amnistía en la transición. Claves de razón práctica, 129. zenb., 14-25 or. Madril: Asociación de revistas culturales de España.

Jünke, C. (2017). Entre historia y memoria. La representación de la guerrilla antifranquista en «Silencio roto» (Montxo Armendáriz, 2001). Foro hispánico: revista hispánica de Flandes y Holanda, 57. zenb, 102-112 or. Brill: Holanda.

Liikanen, E. (2015). El papel de la literatura en la construcción de la memoria cultural: tres modos de representar la guerra civil y el franquismo en la novela española actual. Santiago de Compostela: USC.

Martínez Álvarez, J. (2012). Las películas sobre el maquis español: de la historia oficial a la memoria histórica. Cuadernos de Historia Contemporánea, 34. bol., 225-250 or. Madril: Universidad Complutense de Madrid.

Martínez Gil, F. (2013). La historia y el cine: ¿unas amistades peligrosas? Vínculos de Historia, 2. zenb., 351-372 or. Gaztela-Mantxa: Universidad de Castilla-La Mancha. 
Montiel, A. (2001). Genaro no tiene quien le escriba. La madriguera. Revista de cine, 39. zenb., 55-57 or. Valentzia: Ediciones de intervención cultural S.L.

Pagès i Blanch, P. (2015). Historia y memoria histórica: Un análisis para el debate. Kult-ur, 2. bol, 4. zenb., 127-148 or. Valentzia: Universitat Jaume I.

Rosenstone, Robert A. (1997). El pasado en imágenes. El desafío del cine a nuestra idea de la historia. Bartzelona: Ariel Historia.

Ryan, L. (2014). Deep Memory and the Impossibility of Civil Resistance in Alfons Cervera's Maquis. Hispanic Research Journal. Iberian and Latin American Studies, 15. bol. 338-355 or. Londres: Taylor \& Francis.

Sánchez-Biosca, V. (2005). Políticas de la memoria. La guerra civil española en el cine y el reportaje televisivo. Archivos de la filmoteca: revista de estudios históricos sobre la imagen, 49. zenb. 32-53 or. Valentzia: Instituto Valenciano de Cinematografia.

Saz, I. (2007). El «moment memòria». Justícia, veritat i reconciliació democràtica. Afers: fulls de recerca i pensament, 22. bol. 56. zenb. 27-40 or. Bartzelona: Editorial Afers. 